\title{
STUDII PRELIMINARE PRIVIND AGENTTII DE CONTROL BIOLOGIC AL DĂUNĂTORILOR TOMATELOR ÎN REPUBLICA MOLDOVA
}

\author{
Moldovan Anna 1, 2 , Munteanu-Molotievskiy Natalia ${ }^{1}$, Toderaș Ion ${ }^{1}$ \\ 1 - Institutul de Zoologie, str. Academiei 1, Chișinău, Republica Moldova, \\ e-mail: anna.moldovan@yahoo.com
}

2 - Universitatea de Stat din Moldova, str. M. Kogălniceanu 65A, Chișinău, Republica Moldova https://doi.org/10.53937/9789975315975.52

Tomatele (Lycopersicon esculentum) sunt cultivate pe scară largă, inclusiv în Republica Moldova, constituind sursa principală de venit a unui număr mare de fermieri. Importanța majoră a acestei culturi este determinată de proprietățile ei nutritive și efectele benefice asupra sănătății umane, fiind principala cultură legumicolă utilizată în alimentație, atât în stare proaspătă cât și procesată. În ultimul deceniu suprafața cultivată cu tomate în Republica Moldova a variat între 4-7 mii ha, iar roada medie obținută între 9 și 25 t/ha [8]. Cultura de tomate este atacată de un spectru larg de organisme, printre care insectele, ce pot cauza pierderi considerabile. Insecticidele chimice continuă să fie utilizate ca măsură principală de protecție a tomatelor de dăunători. În Republica Moldova pentru protecția culturii de tomate se folosesc aproximativ 30 de insecticide chimice [9]. Utilizarea pesticidelor creează numeroase probleme ce țin de securitatea oamenilor, apariția focarelor de dăunători secundari, poluarea mediului, reducerea biodiversității și apariția dăunătorilor rezistenți la pesticide [1]. Dependența pronunțată de pesticide precum și de condițiile climatice, a producătorilor locali de tomate, determină necesitatea dezvoltării metodelor sustenabile de management al insectelor dăunătoare. Acestea presupun utilizarea agenților de control biologic cum ar fi parazitoizi, prădători, virusuri, fungi și bacterii. Biopesticidele contribuie eficient la reducerea densității numerice a dăunătorilor și respectiv la diminuarea vectorizării agenților fitopatogeni, având totodată un impact minimal asupra polenizatorilor și altor organisme nevizate [5, 7]. Numeroase specii de bacterii au fost evidențiate în microflora dăună- 
torilor [2], însă puține dintre acestea au fost utilizate în elaborarea biopesticidelor. Pentru controlul lepidopterelor cel mai frecvent se utilizează subspeciile bacteriei Bacillus thuringiensis $(\mathrm{Bt})$ aplicate extensiv în cultivarea legumelor organice și tot mai mult în cadrul sistemelor convenționale [3]. Biopesticidele disponibile în Republica Moldova, sunt limitate la Virin-OS, HS-P și HS-2 "IGFPP" utilizate împotriva dăunătorilor culturilor legumicole Agrotis segetum, A. exclamationis, Autographa gamma și Heliothis armigera [7, 9]. La moment microorganismele sunt încă insuficient explorate și utilizate în managementul insectelor dăunătoare, inclusiv la cultura de tomate, fiind necesare investigații suplimentare.

Scopul cercetărilor constă în izolarea tulpinilor autohtone de Bt pentru a fi utilizate în managementul sustenabil al dăunătorilor tomatelor Helicoverpa armigera și Spodoptera exigua (Lepidoptera). Pentru izolarea selectivă a tulpinilor bacteriene a fost folosit protocolul standard cu unele ajustări. Insectele colectate au fost plasate în eprubete sterile, transportate în laborator și păstrate la temperatura de $4^{\circ} \mathrm{C}$. Corpul insectelor a fost triturat intens în apă distilată sterilă, omogenatul a fost incubat la temperatura de $80^{\circ} \mathrm{C}, 10 \mathrm{~min}$. sau la $65^{\circ} \mathrm{C}, 30 \mathrm{~min}$., după care răcit rapid. Etapa presupune distrugerea formelor vegetative a reprezentanților clasei Bacilli și altor bacterii nesporulate, sporind probabilitatea germinării sporilor bacteriilor din genul Bacillus [4]. Ulterior câte 100, 150 și $200 \mu \mathrm{l}$ și diluțiile decimale ale acesteia au fost distribuite uniform la suprafața cutiilor Petri cu mediul nutritiv T3 steril [6]. Mediul T3 inhibă parțial creșterea și sporularea altor specii din genul Bacillus și favorizează specia $B$. thuringiensis. Cutiile Petri au fost incubate la $30^{\circ} \mathrm{C}$, examinate zilnic și fotodocumentate la a 3-a zi de la însămânțare. Coloniile izolate distincte au fost transferate aseptic în cutii Petri cu mediul T3. Creșterea bacteriană a fost monitorizată zilnic fiind evidențiată prezența unui singur tip morfologic per cutie Petri. Cel mai bun rezultat a fost obținut prin incubare la temperatura de $65^{\circ} \mathrm{C}$ timp 30 min. și însămânțarea a câte $150 \mu$ l omogenat. Metoda prezentată a permis de a selecta aproximativ 60 tulpini care urmează a fi identificate la nivel de specie și evaluată activitatea insecticidă a acestora. Izolarea tulpinilor locale de Bt constituie prima etapă în elaborarea biopesticidelor autohtone ceea ce va permite producătorilor 
locali să ofere pe piață tomate sănătoase, competitive față de produsele de import în ceea ce privește calitatea, prețul și aprovizionarea continuă, sporind veniturile fermierilor și dezvoltând economia națională.

\section{BIBLIOGRAFIE}

1. Damalas C.A., Eleftherohorinos I.G. 2011. Pesticide Exposure, Safety Issues, and Risk Assessment Indicators. Int. J. Environ. Res. Public Health, 8(5), p. 1402-1419.

2. Jurat-Fuentes, J.L., Jackson, T.A. 2012. Bacterial entomopathogens. In: Vega, F.E., Kaya, H.K. (Eds.), Insect Pathology, second ed. Academic Press, San Diego, p. 265-349.

3. Kati H., Sezen K., Nalcacioglu R., Demirbag Z. 2007. A highly pathogenic strain of Bacillus thuringiensis serovar kurstaki in lepidopteran pests. J. Microbiol 45(6), p. 553-7.

4. Manual of Techniques in Invertebrate Pathology, $2^{\text {nd }}$ Ed. 2012. L. Lacey (Ed.), Academic Press, eBook ISBN :9780123869005, 504 p.

5. Mudgal S., De Toni A., Tostivint C., Hokkanen H., Chandler D. 2013. Scientific Support, Literature Review and Data Collection and Analysis for Risk Assessment on Microbial Organisms Used as Active Substance in Plant Protection Products - Lot 1 Environmental Risk Characterization. EFSA Supporting Publications, EN-518. 149 p.

6. Travers R.S., Martin P. A. W., Reichelderfer C. F. 1987. Selective process for efficient isolation of soil Bacillus sp. Appl. Env. Microbiol., 53, p. 12631266.

7. Volosciuc L. 2015. Realizări în protecţia microbiologică a plantelor. Akademos, 3, p. 57-64.

8. www.statistica.md, Statistici pe domenii, Agricultura, Cultura plantelor, (accesat la data 02.08.2018)

9. www.pesticide.md/registrul-de-stat/ (accesat la data de 03.08.2018) 